\title{
Closing of water circuits - a global benchmark on sustainable water management
}

\author{
Siegmund Fröhlich ${ }^{1, *}$ \\ 1Process Engineering @ Hochschule Emden/Leer, Constantiaplatz 4, D26723 Emden
}

\begin{abstract}
Access to clean water resources has always been a crucial factor in the history of mankind. Now, in the $21^{\text {st }}$ century, water, as an increasingly scarce resource, will take a strategic role for the future development of global populations. As the former UN Secretary General Dr. Dr. Boutrous Boutrous Ghali predicts: "The wars of the $21^{\text {st }}$ century will be fought not over oil, they will be fought over water." [1]. In nine global examples will be demonstrated the different ways of dealing with water resources. That are: Mexico City, Egypt, Libya, DOW Terneuzen, Los Angeles, Israel, China and Singapore and also global trends, such as, scarcity \& rural exodus and salinization of soil. Thereby, he explains the different kinds of water management to be observed. The most relevant prognosis of the $\mathrm{WHO}$ is, that to the end of $21^{\text {st }}$ century Africa's population will grow over proportionally from 1 billion now up to nearly 4 billion [9]. That is why all efforts need to be concentrated on helping Africa create a sustainable economic development. The first and by far most important strategic step is to assure access to clean water resources in the rural and mostly arid regions of the continent. The lecturer shows several technological proposals on how to overcame problems like: water scarcity, rural exodus, salinization of soil and others. Such technologies could be successfully implemented in sustainable development programs in African countries.
\end{abstract}

\section{Global benchmark of sustainable water management}

In nine global examples inclusind four typical phenomena it will be shown how different depending on local and economic situation - the water management worldwide is.

\subsection{Egypt as river oasis}

Water management in Egypt has been exceptionally from the beginning. Only 4\% of Egyptian soil are suitable for agricultural use. This includes the riverside and, especially, the Nile delta, which is highly cultivated and densely populated. Due to constantly increasing population growth many new channels and irrigated land areas are currently under construction.

\footnotetext{
*Corresponding author: procesconsult@,t-online.de
} 
Over centuries, the White Nile River has been transporting million tons of intensely fertile mud to nourish the adjacent cultivation areas. Also, volcano ash from highlands of Ethiopia, transported by the river, served as the best natural fertilizer for the Egyptian soil, and has assured the country's prosperity over thousands of years. Another positive side effect concerns the salt, which has been transported away from the fields by the yearly floodings [6].

This changed with the construction of the Aswan High Dam in 1971. The water capacity of the dam is: $\approx 130.000-170.000 \mathrm{~km}^{3}$ water. It is worldwide the $7^{\text {th }}$ biggest water reservoir which delivers $\approx 2.1 \mathrm{GW}$-electrical power - to provide the Egyptian industry with power. However, after the commissioning of the dam, only a small amount of natural fertilizer reaches the agricultural areas of Egypt.

That means the dam has both positive and negative effects on the industry and agricultural landscape. On the one hand, it prevents devastation by flooding and brings power for industrialization. On the other hand, the salt load of the conventional oasis cannot be washed out of the soil and consequently compromises the fertility of the fields. As such, Salinization of the soil currently poses the greatest threat to Egyptian agriculture producing million tons of non-fertile salty soil every year [6].

To overcome that, the lecturer is proposing the establishment of mobile soil washing plants in which the salt content could be extracted to reuse the purified soil. With a throughput of $125 \mathrm{~m}^{3} / \mathrm{h}$ the plant can wash and purify up to 100 tons of desalinated soil per day, which can then be reintroduced to the agricultural cycle.

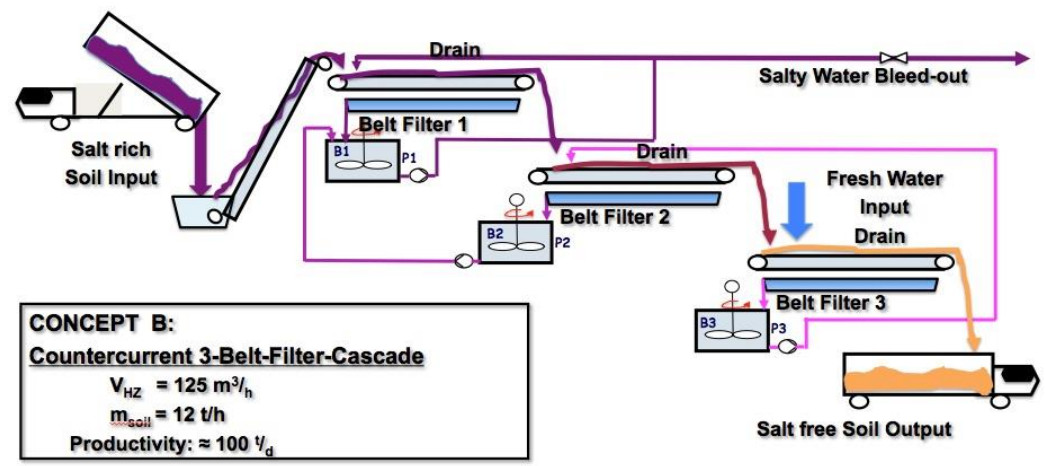

Fig. 1. Mobile Soil Washing Units for Egypt Salty Soil Remediation [7].

\subsection{Ground water overexploitation in Mexico megacity}

Until the conquista, the Spanish conquest of Mexico in 1519, the Aztec Empire was ruled by its capital city Tenotchtitlan. The population, approx. 100000 inhabitants, was relatively big for a city of that time. The city was situated $2200 \mathrm{~m}$ above sea level within the holy Texcoco Lake - accessible only via five dams. Access to the city was strictly controlled and regulated. However, very unfortunate for the Aztecs, their ancient beliefs in myths and "white goddesses that will revisit the earth" misled them to giving the Spanish conquerors easy access to their holy city, who exploited it thereupon.

Tenochtitlan was devastated, the holy lake drained and the Hispanic colony town of Mexico City was erected in the same place. Today, Mexico is one of the worlds' so-called Mega Cities counting approx. 22 million inhabitants. Only $20 \%$ of drinking water can be acquired via rainfall from surrounding mountains. The remaining portion is acquired from contaminated ground water. Caused by the tremendous thirst of Mexico City more than 3000 wells were drilled to acquire ground water from a depth of up to $400 \mathrm{~m}$. But the 
ground water is highly polluted, because the lion share of municipal and industrial wastewaters is not purified before being discharged into the ground water stock.

In addition, the ground water level constantly keeps declining, increasing the costs and difficulty to acquire water. However, during spring season heavy rainfall and flooding cause temporary collapses of the city's drinking water grid. It is outdated and extremely morbid which is why up to $1 / 3$ of drinking water disappears in leakages. All in all, this means that each citizen "consummates" round about 300 litres of water daily. Only the small share of rich people living in Mexico City can afford to buy good drinking water [8].

Only $10 \%$ of Mexico City's wastewaters are treated in municipal wastewater treatment plants. Industrial wastewater is generally not treated at all. There is even no basic separation between "grey" and "black water" in order to reuse the lower polluted share of water. After just one single usage the tremendous portion of $170 \mathrm{~m}^{3} / \mathrm{sec}\left(620.000 \mathrm{~m}^{3}\right.$ per hour) of Mexico City's wastewaters, the so called "aqua negra" - is directly discharged into ocean.

Several actions need to be started in order to overcome this situation:

1. It starts initially by raising awareness to change the situation through education in schools and industry.

2. The next step is to repair the old water grid, replace it in parts and extend it which is an essential step to lower the overall water consumption.

3. Then, new water retention and buffer reservoirs need to be established.

4. Furthermore, modern municipal wastewater plants need to be installed.

5. Finally, water recycling and multi usage systems need to be introduced to industry and municipal management authorities.

Although there are plenty of good proposals, the government has remained unwilling to change or even acknowledge the urgency of the situation. Mr. Lopez Meija, Biology Expert of the Environmental Dpt. of Mexico City is quite sceptic. To him, as long as living in the city is more attractive for the people than living on the countryside, no politician can counteract rural depopulation and tremendous growth of the Megacity Mexico [8].

\subsection{Worldwide rural depopulation and megacities growth in Africa}

The biggest challenge of the $21^{\text {st }}$ Century lies in finding sustainable ways of how to manage water as the rare resource it is while considering the estimated global population growth by the year 2100 .

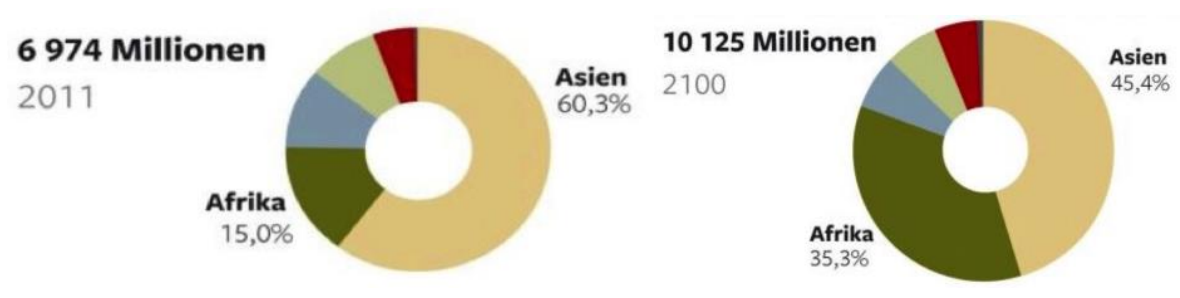

Fig. 2. Global population shifts in the $21^{\text {st }}$ century [9].

On the basis of data provided by [9]. The African continent faces the most dramatic demographic development of this century. According to this prognosis, the number of Africans now, will have quadrupled up to the year 2100 .

As a consequence, migration from Africa to Europe will intensify dramatically. To plan ahead and avoid massive future migration flows, the European governments have to 
launche plenty of sustainable development aid programs in African countries to counteract the African emigration and rural depopulation.

In light of this prognosis, the lecturer proposes, that in costal regions with stabile wind conditions it would be very helpful to establish wind converters to provide the energy for water desalination plants. Those plants could be installed in movable containers for a quick installation, especially, in case of natural disasters and rising local demand [10].

At a daily production rate of approx. $1.000 \mathrm{~m}^{3}$ of such a plant, a water demand for up to 20.000 people could be covered. In countries with good maintenance service e.g. reverse osmosis plants could be established to desalinate sea water. In countries with less maintenance level more robust vapour compression plants could be installed. For those robust technology maintenance service could be assured by local mechanical workshops. Such modular systems are not only suitable for villages and small cities but also for hotels und industrial purposes as well.

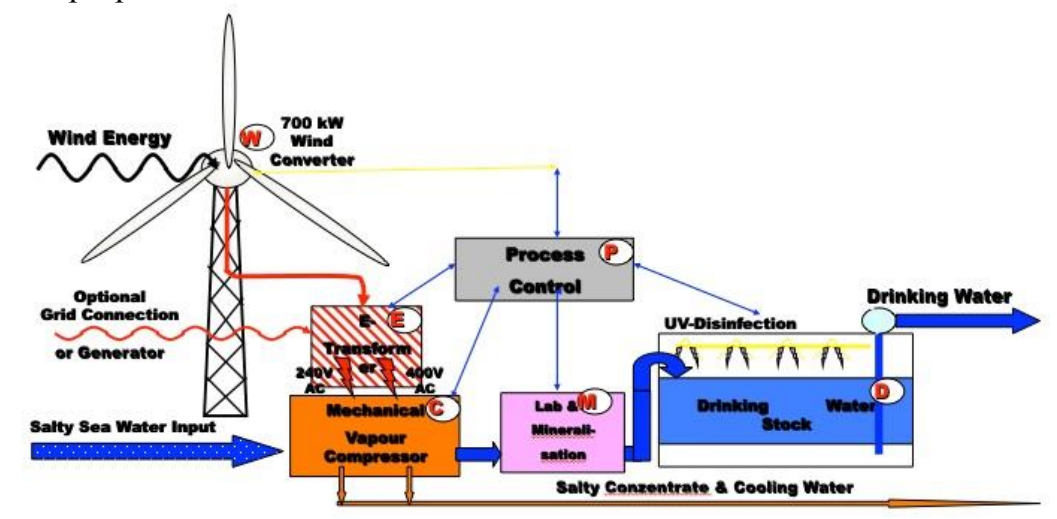

Fig. 3. Mobile Desalination Plants for Sustainable Development [10].

\subsection{The Great Man Made River - GMMR-Project in Libya}

Currently, almost every Libyan river faces water scarcity. This comes as no surprise, considering the fact that $95 \%$ of Libya's land is dominated by a barren desert landscape allowing agriculture only in the coastal regions. The ground water stocks by the coast are, however, heavily contaminated with salt. Plenty solutions to solve Libya's problem with water scarcity were explored to satisfy the rising water demand of Libya.

Quite fascinating, that under the Sahara Desert there is an approx. 373.000 billion $\mathrm{km}^{3}$ underground fossil water reservoir from the Ice Age. The so called Nubian Aquifer is the largest sweet water basin of the world. Following experts' prognosis, approximately 9.000 billion $\mathrm{km}^{3}$ of that water deposit could be used. As UN-Centre for Environmental Development of the Arabic Region \& Europe - CEDARE in Cairo calculate - Those waters are good for maximum of 4.860 years. [11]

In the aftermath of the discovery of the underground lake, the Great Man-Made River (GMMR)- Project was established. Mr. Abdelmagid El Gaood from the Libyan Ministry of Agriculture, is the general project chief who advised to build 467 water wells in the centre of Sahara which are currently accessing the reservoir and supplying 6 million $\mathrm{m}^{3}$ of water per day. Some of $\mathrm{CO}_{2-}$, Mn- und Fe-containing waters had to be purified in special water treatment plants. The concrete water pipes have to be resistant at 60 bar pressure.

To date, this is the most monumental water project on earth. The total project shall be finished by the year 2030 with estimated costs of approx. 27 billion $€$. According to Libyan 
experts, the water amount is sufficient for the next 50 up to 250 years. By $25 €$-Cent per $\mathrm{m}^{3}$ is such mammoth project the cheapest one in drinking water production [11].

\subsection{Water overexploitation by the city of Los Angeles}

The City of Los Angeles has approx. 3,8 million inhabitants and it is the $2^{\text {nd }}$ biggest in the USA. The wider LA region counts 17,8 million inhabitants. The LA metropolis is ranked on place $17^{\text {th }}$ of all metropolis regions of the world by the number of inhabitants. LA consummates more than $50 \%$ of the water resources of the total California State. Only a great irrigation grid network can supply the demand of such an immensely thirsty region.

Therefore, a gigantic wastewater treatment plant was built. The American Public Works Association (APWA) has chosen the so called "Hyperion Project" as one of the Top Ten Projects of the $20^{\text {th }}$ century, which had the same ranking as Panama Chennel, Hoover Dam $\&$ the Golden Gate Bridge. [13]

The Biomass of the plant was utilized initially in a so called Biosolids-to-FertilizerProgram as fertilizer for agriculture. The Environmental Protection Agency (EPA) stopped this procedure in 1980 because of the accumulation and increase of heavy metals in the soil. In 1998, the treatment plant was reconstructed and its capacity was adjusted by 800.000 $\mathrm{m}^{3} / \mathrm{d}$. Nowadays, the biosludge of the plant is converted into biogas. By means of such treatment the biosludge discharging could be minimized by $95 \%$.

An exceptional method of water saving and reusing was developed here to satisfy the huge water demand Los Angeles. By infiltration of purified waste water into the ground, this water re-joins the ground water stock which is additionally filtered by the natural Volcanic porous rock. This special kind of rock contains Zeolites and Bentonite minerals, that additionally purify the water when it seeps through the porous rocks. The water quality is constantly monitored and controlled in monitoring wells. Later, in production wells, the purified water can be again retrieved and serve as drinking water.

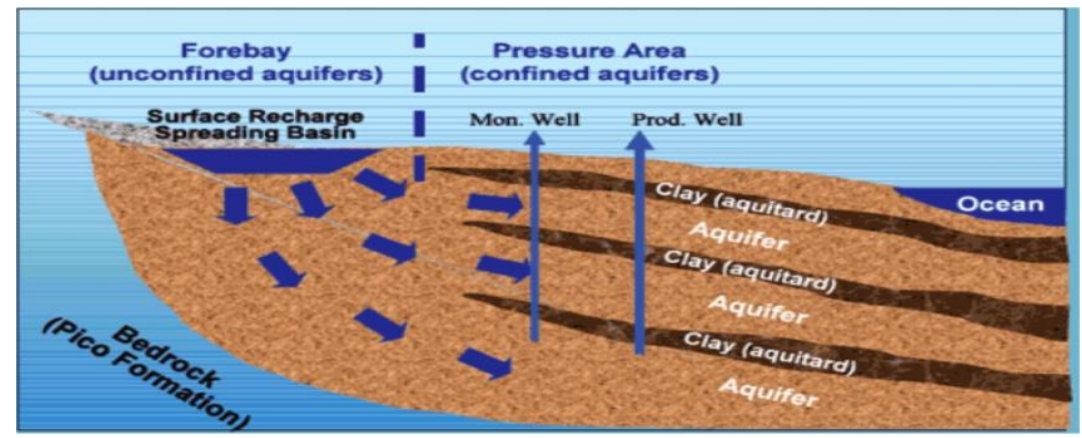

Fig. 4. Recovery \& Reuse of Treated Wastewater in a Final Purification by Penetration of Volcanic Rocks [12]

The careful dealing with the water resource in California led to new markets and helped to increase the economic development of the region thanks to a number of activities:

1. The awareness and acceptance of the public to start such non-conventional ways of saving and reusing purified water.

2. Awareness raising in schools and public places.

3. Giving new incentives and impulses to municipal waste water treatment.

4. Installing efficient ground water pumps that help close water circuits to minimize water loss.

5. Finally, installing new desalination plants that further increase water safety [5]. 


\subsection{Xiaolangdi dam as a pattern for new infrastructure projects in China}

The rising energy demand of China can be covered only by a mid-term fossil energy sources policy. Gigantic infrastructure programs of hydro- and renewable energy power stations have a longer term for realisation. According to Yves Rannou, Alstom Chef in CHN, China's hydropower is already exceeding by $15 \mathrm{GW}$ per year (2015).

The new extraordinary dam project shall help to solve several infrastructural problems:

1. The Yellow River sediments rises the river level by $10 \mathrm{~cm}$ a year. The Xiaolangdi Dam shall store the clay river sediments for the next 20 years.

2. 30 million tons of clay mud are discharged a year by the dam base outlets.

3. In the last 13 years, over 390 million tons of clay mud discharged.

4. The dam also prevents flooding

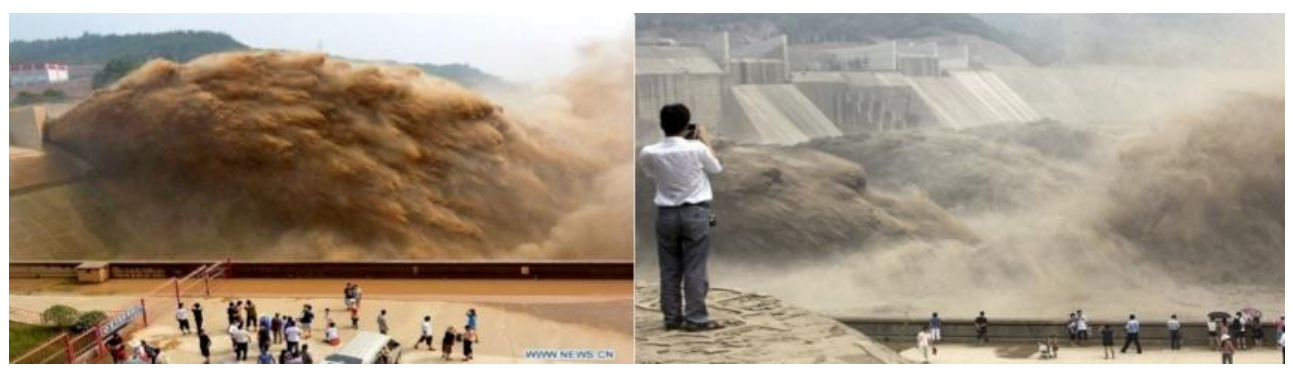

Fig. 5. Clay Mud Discharge at the Xiaolangdi Dam Base in China [15].

\subsection{Sustainable water management of DOW Terneuzen \& its region}

DOW Chemical and the Biesbosch Waterboard Region have realised the most successful integrated Municipal \& Industrial Wastewater Management in Europe. For the DOW Company it was essential to grant safe access to 22 million $\mathrm{m}^{3} /$ year to assure the prosperity of the chemical company.

DOW as a polymer and membrane producing company has made a strategic decision to utilize its own Reverse Osmosis membranes widely to cover its own great water demand.

In 2010, 35\% of DOW's fresh water demand was covered by the Biesbosch Region. $65 \%$ had to be acquired by internal \& external Reverse Osmosis water recycling action. By the year of 2015 - Thanks RO \& Energy Recovery - a recycling ratio for fresh water of nearly $80 \%$ could be realized. The target of the year 2020 is - Thanks RO \& Energy Recovery - a $100 \%$ recycling ratio for fresh water. This means that the company is on its way to become the best practice example in Sustainable Water Management in Europe.

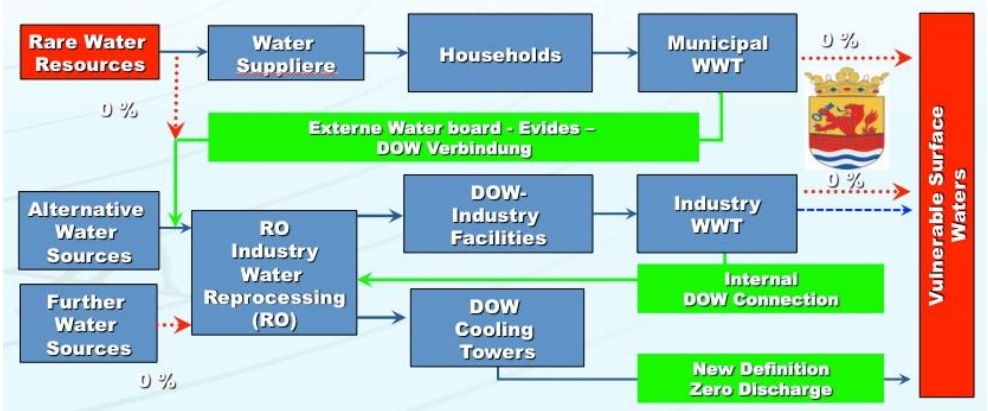

Fig. 6. DOW Benelux Sustainable Total Water Management at Terneuzen [16]. 


\subsection{The Jordan River water resources in permanent dispute in Near East}

Sharing such a very rare resource as Jordan water in that part of the earth is quite difficult. The demographic growth of the neighbour nations has led to a complete disappearing of the Jordan River at entering the Dead Sea since more than 20 years. Intensive agriculture have brought the Jordan River to dray up - The water level of the Dead Sea is permanently descending. The south part of the Dead Sea is drying out. There are even plans to construct a pipeline from the Red Sea - including a power station - to save the Dead Sea.

Therefore unconventional solutions in water usage had to be chosen:

Israel had to choose and to define new ways and politics to get reliable water resources:

1. Israel engineers were the technological pacemakers in terms of droplet irrigation.

2. Rain buffering and storage of rainwater resources in ground water reservoirs was essential to survive in that region.

3. Aquaponic - an inventory fish farming and vegetable production was born.

4. The recycling of purified municipal wastewater was successfully utilized similar as in California.

5. Finally three great sea water desalination Plants - utilizing energy recycling modules - have assured very safely the rising water demand of the country [14].

By those step by steps measures Israel is nowadays able to export „,virtual water“ in kind of agricultural products into the global market [17]. And the droplet irrigation, invented in Israel, is actually implemented in any successful agricultural farming around the Mediterranean Sea.

\subsection{Global benchmark No. 1: total water management of the megacity Singapore}

Only 40 years ago, today's agile metropolis city Singapore had totally insufficient water supply. Located on an island, without any lakes or water retention basins (to buffer the storm rainfall) nearby, almost all water had to be imported by the neighbouring country Malaysia. Nowadays, Singapore is the leading world nation, which could change his great disadvantages completely by an inventory water policy and technology [17].

That situation could be reached only:

1. By wide programs for awareness changes on water policy.

2. By extended education programs at schools and in the industry.

3. By setting of appropriate prices for water consumption.

4. By erection of new water retention- and buffer basins.

5. By exceptional unique total recovery $\&$ recycling of waste water.

6. By implementation of modern technologies for seawater desalination.

So the megacity Singapore is nowadays - thanks its excellent economic prosperity - the shiny and Best Practice Example of Sustainable Total Water Management in the world. 


\section{Conclusions}

Presented nine global examples demonstrate how different - depending on local and economic situation - the water management worldwide is. In rich countries there are all technological and economical solutions available to support the inhabitants with excellent quality and adequate portion of drinking water. In wide regions of Africa, Asia and South America the population suffers much of extremely intensifying scarcity.

But the biggest challenge of the $21^{\text {st }}$ Century lies in finding sustainable ways of how to manage water as the rare resource it is while considering the estimated global population growth by the year 2050 and 2100 . To plan ahead and avoid massive future migration flows - especially from Africa - the European governments has to launch plenty of sustainable development aid programs in African countries to counteract the African emigration and rural depopulation.

In the light of this prognosis, the lecturer proposes two possible technological solutions helping to minimize the global scarcity problems:

- Wind power driven water desalination plants and

- Mobile soil desalination plants,

which could be implemented in those development aid programs.

\section{References}

1. www.sourcewatch.org/index.php?title=Water_wars

2. K. Hancke, Wasseraufbereitung, Springer (2003), ISBN 978-3540068488

3. W. Lorch, Handbook of Water Purification (Ellis Horwood Books, 1998)

4. P. Gleick, Basic water requirements for human activities: Meeting basic needs Pacific Institute for studies in development, environment and security in Water International 21, 83-92 (1996)

5. M. Elimelech, W.A. Phillip, Energy, Technology, and the Environment, Science, 333 (2011)

6. 3Sat-Mediathek: Dirk Steffens "Die Macht der Elemente \#2 Wasser"

7. Siegmund R. Fröhlich: Own Proposal "Mobile Soil Washing Units"

8. www.daserste.de/information/politik-weltgeschehen/weltspiegel/videos/mexikowasser-fuer-reiche-jauche-fuer-arme-100.html

9. www.welt.de/wissenschaft/umwelt/article117275819/Menschen-haben-bald-nichtmehr-genug-Nahrung.html

10. S.R. Fröhlich: Own Proposal "Smart Wind Powered Desalination Plants"

11. www.zeit.de/wissen/umwelt/2010-12/libyen-wasser

12. www.wrd.org/water_quality/recycled-water-groundwater-recharge.php

13. www.water-technology.net/projects/hyperion

14. Stover, R.L., Low Energy Consumption SWRO Energy Recovery, Inc., San Leandro, CA USA.

15. Www.water-technology.net/projects/shanxi

16. /www.dow.com/benelux/

17. www.scientificamerican.com/article/israel-proves-the-desalination-era-is-here/

18. www.cscollege.gov.sg/Knowledge/ethos/Issue\%202\%20Apr\%202007/Pages/WaterManagement-in-Singapore.aspx 